Bartłomiej BISKUP

Uniwersytet Warszawski

Karolina CHURSKA-NOWAK, Sebastian DROBCZYŃSKI

Wyższa Szkoła Nauk Humanistycznych i Dziennikarstwa, Poznań

Agnieszka HESS

Uniwersytet Jagielloński, Kraków

Mariusz KOLCZYŃSKI, Marek MAZUR

Uniwersytet Śląski, Katowice

Dorota PIONTEK, Szymon OsSOWSKI

Uniwersytet im. Adama Mickiewicza w Poznaniu

\title{
Relacjonowanie wyborów samorządowych w prasie regionalnej w 2010 roku. Komunikat z badań
}

\begin{abstract}
$\mathrm{M}$ edia regionalne odgrywają istotną rolę w samorządowej kampanii wyborczej. Stwierdzenie to - tyleż oczywiste co banalne, wymaga jednak komentarza i szerszego, głębszego namysłu. Temat jest niezwykle istotny, chociażby ze względu na postępującą mediatyzację i profesjonalizację polityki na poziomie lokalnym, ale wydaje się być marginalizowany, zwłaszcza w porównaniu z badaniami dotyczącymi wpływu mediów na przebieg kampanii wyborczych o zasięgu ogólnokrajowym. Większość prób analizy wpływu mediów regionalnych na przebieg i w konsekwencji pośrednio również wynik wyborów, ma charakter bardziej publicystyczny niż naukowy. Dotyczy to nie tylko dziennikarzy i publicystów, lecz również opisów i ocen przeprowadzanych przez badaczy tej problematyki. Słabość tego rodzaju analiz jest często efektem braku odpowiedniej metody badawczej lub niechęci do prowadzenia badań, które mogą być postrzegane jako fragmentaryczne. Większość naukowych analiz poświęconych mediom w samorządowych kampaniach wyborczych ma charakter typowo jakościowy i rzeczywiście odnosi się do konkretnego regionu. Intuicja nawet najbardziej doświadczonego badacza, niepoparta twardymi danymi ilościowymi, po prostu nie wystarcza. Warunkiem sine qua non dobrej analizy jakościowej jest oparcie się na przeprowa-
\end{abstract}


dzonym uprzednio badaniu ilościowym. Brak analizy ilościowej w efekcie prowadzić musi badacza na pola publicystyki. Potrzeba prowadzenia takich badań wydaje się być więc bezdyskusyjna.

\section{Mediatyzacja kampanii wyborczych}

Jednym z głównych powodów podjęcia badań nad relacjonowaniem kampanii wyborczych przez media regionalne jest postępujący proces mediatyzacji kampanii wyborczych. Dokonuje się on zarówno na szczeblu ogólnopolskim, jak i podczas rywalizacji samorządowej. Można odnieść wrażenie, że tak jak mnogość badań nad znaczeniem mediów w wyborach ogólnokrajowych staje się powoli problemem, tak samo jest nim brak analogicznych badań uwzględniających specyfikę kampanii samorządowych. Jakby zapominano, że choć wybory te różnią się od siebie pod wieloma względami, w tym specyfiką mediów je relacjonujących, to jednak sam proces mediatyzacji dotyka wszystkie poziomy wyborczej rywalizacji, a zasady nimi rządzące są porównywalne.

Mediatyzacja kampanii wyborczych zawiera w sobie dwa kluczowe aspekty. Z jednej strony polega na dopasowywaniu się podmiotów politycznych do zmieniających się warunków osiagania przez nie sukcesu W społeczeństwie medialnym i informacyjnym ${ }^{1}$. Z drugiej strony, pod-

Zob. m.in. H. M. Kepplinger, Demontaż polityki w spoleczeństwie informacyjnym, Wydawnictwo Uniwersytetu Jagiellońskiego, Kraków 2007; Massenmedien als politische Akteure, VS Verlag für Sozialwissenschaften, red. B. Pfetsch, S. Adam, Wiesbaden 2008; Mediendemokratie, red. P. Massing, wyd. II, Wochenschau Verlag, Schwalbach 2004; B. Hombach, Medien als Akteur und Instrument der Politik, Gedanken zur Zukunft, Herbert Quandt Stiftung, Bad Hamburg 2004; H. Boventer, Medien und Demokratie, Universtitätsverlag Konstanz GmbH, Konstanz 2004; S. N. Soroka, Media, Public Opinion, Foreign Policy, „The Harvard International Journal of Press/Politics" 2003, no 8, s. 27-48; T. Goban-Klas, Media i komunikowanie masowe. Teorie $i$ analizy prasy, radia, telewizji i internetu, PWN, Warszawa 1999; M. Mrozowski, Media masowe. Władza, rozrywka i biznes, Oficyna Wydawnicza ASPRA-JR, Warszawa 2001; S. Michalczyk, Komunikowanie polityczne. Teoretyczne aspekty procesu, Wydawnictwo „Śląsk”, Katowice 2005; B. Dobek-Ostrowska, Media masowe i aktorzy polityczni w świetle studiów nad komunikowaniem politycznym, Wydawnictwo Uniwersytetu Wrocławskiego, Wrocław 2004; A. Hess, A. Szymańska, Pomost medialny. Międzynarodowa komunikacja polityczna na przyktadzie relacji polsko-niemieckich, Wydawnictwo Uniwersytetu Jagiellońskiego, Kraków 2009, s. 134-137. 
mioty biorące w nich udział sprawnie posługują się mediami, wykorzystując możliwości, jakie daje im ich obecność ${ }^{2}$. Co więcej, obywatele zależni są od mediów, kiedy poszukują informacji dotyczącej wyborów i kandydatów, z kolei dla podmiotów rywalizacji przekaz medialny jest swoistym miernikiem nastrojów i opinii społecznych. W tym sensie, medialne rekonstrukcje rywalizacji wyborczej moga wywierać wpływ na postrzeganie rzeczywistości politycznej przez odbiorców mediów, a także na przebieg samej kampanii.

\section{Założenia badawcze}

Mediatyzację kampanii wyborczej w naszym studium odnosimy do roli przekazu medialnego w przedstawianiu oferty politycznej podmiotów rywalizujących o głosy wyborców, w znacznej mierze odbiorców mediów, oraz do potencjalnego wpływu, jaki może wywierać sposób prezentowania rywalizacji samorządowej $\mathrm{w}$ mediach regionalnych na zbiorowe wyobrażenia dotyczące samych wyborów oraz możliwych rozwiązań politycznych w przyszłości powyborczej.

Przyjęto założenie, że media regionalne są jednym z głównych nośników informacji na temat lokalnej rywalizacji samorządowej i jednocześnie aktywnym uczestnikiem procesu komunikacji politycznej kształtującym lokalną opinię publiczną, a przez to mającym wpływ na preferencje wyborcze odbiorców. Założenie to wynika zarówno z przesłanek odnoszących się do ogólnych właściwości mediów, jak i do specyficznej roli mediów w lokalnej komunikacji politycznej.

Po pierwsze, poprzez obróbkę informacji w procesach selekcji, tworzenia i interpretacji, media nie tylko przekazują odbiorcom wiadomości pochodzące od podmiotów rywalizacji politycznej, ale zabierają istotny głos na temat polityki. Jednocześnie, relacjonując i analizując działania polityczne stanowią ich integralną część jako dostępne zasoby dla aktorów politycznych biorących udział w wyborach ${ }^{3}$.

Po drugie, chociaż media tradycyjne już dawno utraciły monopol na informację, to nadal w znaczącym stopniu determinują agendę władzy, instytucji publicznych i podmiotów rywalizujących w wyborach, które z kolei dostosowują się do logiki funkcjonowania mediów, aby za ich

2 W. Schulz, Politische Kommunikation, wyd. II zmienione, op. cit., s. 324.

3 B. McNair, Wprowadzenie do komunikowania politycznego, Poznań 1998, s. 66. 
pośrednictwem dotrzeć do jak najszerszej grupy obywateli, ponosząc jak najmniejsze koszta.

Po trzecie, w warunkach rywalizacji samorządowej szczególnego znaczenia nabierają media regionalne, które systematycznie, „dzień po dniu”, relacjonują proces kampanii wyborczej na różnych jej szczeblach, tworząc swoistą reprezentację polityki, ale przede wszystkim odnoszą się do życia i charakteru społeczności w wymiarze regionalnym i lokalnym ${ }^{4}$.

Po czwarte, dla polityków walczących o utrzymanie swojej obecności w strukturach władzy samorządowej, a także dla kandydatów, których celem jest zaistnienie na lokalnej scenie politycznej, media regionalne są jednocześnie źródłem wiedzy o nastrojach społecznych, kanałami prezentacji ich poglądów politycznych, programu działania, kreowania wizerunku oraz zwierciadtem, w których odbijają się ich aktywności, poglądy i opinie obywateli/wyborców o nich jako politykach ${ }^{5}$. Mediatyzacja kampanii wyborczych polega między innymi na dostosowywaniu się podmiotów rywalizujących w wyborach do warunków prowadzenia kampanii $\mathrm{w}$ regionalnej przestrzeni publicznej zdominowanej przez media.

Wreszcie, po piąte, rywalizacja samorządowa jest dla mediów regionalnych okazją do pozyskania potencjalnych odbiorców interesujących się polityką lokalną oraz do podniesienia ich rangi i znaczenia w wymiarze konkurencji na rynku mediów. Samorządowa kampania wyborcza wzmacnia znaczenie regionalnych mediów drukowanych w tym sensie, że w o wiele szerszym zakresie mogą one realizować zadanie relacjonowania rywalizacji toczącej się w poszczególnych jednostkach terytorialnych. Dlatego przy analizie mediatyzacji rywalizacji samorządowej trzeba brać pod uwagę także taktyki stosowane przez same media celem uatrakcyjnienia przekazu na temat wyborów samorządowych.

Niniejszy artykuł przedstawia metodologię oraz fragmentaryczne wyniki badań empirycznych dotyczących profesjonalizacji i mediatyzacji samorządowej kampanii wyborczej przez pryzmat relacjonowania kampanii na łamach prasy regionalnej, przeprowadzone przez zespół badaczy z czterech ośrodków naukowych w kraju, w ramach projektu

4 A. Lutrzykowski, M. Legiędź-Gałuszka, ,Wspólnota samorzqdowa” czy ,,spoteczność lokalna” (regionalna)? Spór nie tylko semantyczny, w: Samorzqd terytorialny w Polsce $i$ w Europie (doświadczenia i nowe wyzwania), red. J. Marszałek-Kawa, A. Lutrzykowski, Wydawnictwo Adam Marszałek, Toruń 2008, s. 9-33.

5 S. Michalczyk, Komunikowanie polityczne..., op. cit., s. 129. 
badawczego pt.: „Wybory samorządowe w mediach regionalnych. Dzienniki regionalne i telewizyjne audycje wyborcze jako platformy komunikacji politycznej". Jednym z celów projektu jest właśnie analiza sposobu relacjonowania kampanii wyborczej w prasie regionalnej podczas kampanii samorządowej w Polsce z 2010 roku. Zastosowano metodę analizy zawartości, w ujęciu ilościowym i jakościowym, wypowiedzi prasowych na temat wyborów, zebranych w okresie dwóch ostatnich tygodni kampanii wyborczej przed wyborami z 21 listopada 2010 roku, w dodatkach regionalnych drukowanych wydań „Gazety Wyborczej” oraz mutacji regionalnych „Polska The Times” w czterech stolicach miast wojewódzkich - Katowicach, Krakowie, Poznaniu i Warszawie (są to dzienniki, które ukazują się we wszystkich badanych regionach) ${ }^{6}$. Jednostką badawczą w wypadku gazet była wypowiedź prasowa (jwp) na temat wyborów.

Podstawowe pytania badawcze dotyczyły udziału problematyki wyborczej w gazetach regionalnych, ekspozycji poszczególnych tematów, dominujących poziomów rywalizacji relacjonowanych w przekazach, funkcji gazet regionalnych w wyborach samorządowych, także w ujęciu porównawczym na poziomie regionów i tytułów gazet. Celem badania jest bowiem, w oparciu o wyniki analiz treści regionalnej prasy informacyjnej, analiza funkcji, jakie dzienniki regionalne pełnią w odniesieniu do rywalizacji samorządowej z perspektywy potencjalnych wyborców, $\mathrm{z}$ jednej strony, i podmiotów rywalizacji samorządowej, z drugiej strony. W centrum zainteresowania znajdują się zatem modele zachowań poszczególnych tytułów w odniesieniu do rywalizacji samorządowej, w wymiarze regionalnym.

Fragmentaryczne wyniki badań przeanalizowane w niniejszym tekście są efektem ogólnej analizy porównawczej sposobu relacjonowania kampanii wyborczej w czterech badanych miastach oraz przede wszystkim szczegółowej analizy sposobu relacjonowania kampanii w Poznaniu na łamach dzienników „Polska - Głos Wielkopolski” oraz „Gazety Wyborczej - Poznań”. Omówiony tu przykład Poznania ma charakter pilo-

6 Całość wyników badań zostanie zaprezentowana w odrębnej publikacji. Projekt jest efektem współpracy międzyuczelnianej grupy badaczy komunikowania politycznego utworzonej w 2010 r. Pierwsze wyniki studiów tej grupy nt. zmian modernizacyjnych komunikowania politycznego w Polsce przedstawiono w publikacji pod redakcją Karoliny Churskiej-Nowak oraz Sebastiana Drobczyńskiego pt.: Profesjonalizacja i mediatyzacja kampanii politycznych w Polsce (Poznań 2011). 
tażowy. W podobny sposób zostaną przeanalizowane i opisane pozostałe miasta, a następnie w publikacji zwartej na podstawie tych danych dokonana zostanie analiza porównawcza i zostaną wciągnięte wnioski o bardziej ogólnym charakterze co do sposobu relacjonowania wyborów samorządowych w mediach regionalnych.

\section{Relacjonowanie samorządowej kampanii wyborczej w poznańskich mediach regionalnych - fragmentaryczne wyniki badań}

Pierwszą różnica, która została zaobserwowana już na wstępie, jest liczba jednostek wypowiedzi prasowych w poszczególnych miastach i tytułach, poświęconych wyborom. W Poznaniu w ciagu dwóch badanych tygodni odnotowano 137 tekstów poświęconych wyborom, przy jedynie 68 w Warszawie, 97 w Katowicach i aż 169 w Krakowie. Zdecydowanie najmniejsza liczba tekstów w gazetach warszawskich wynika po części najprawdopodobniej ze specyfiki warszawskiego rynku prasowego i braku na nim lokalnego dodatku do dziennika „Polska The Times”, a więc odpowiednika poznańskiego „Głosu Wielkopolskiego”, katowickiego „Dziennika Zachodniego” i „Gazety Krakowskiej”. „The Times" w Warszawie opublikował jedynie 24 teksty dotyczące wyborów, przy 77 „Głosu Wielkopolskiego” i aż 94 „Gazety Krakowskiej”. Z kolei „Gazeta Wyborcza” w Warszawie zamieściła 44 materiały, dwa razy więcej niż warszawski „The Times”, aczkolwiek i tak najmniej jeżeli porównać to z innymi miastami. W Katowicach "Gazeta Wyborcza” opublikowała 54 teksty o tematyce wyborczej, w Poznaniu 60, a w Krakowie aż 75 jednostek wypowiedzi prasowych (patrz tabela poniżej).

Tabela

Liczba jednostek wypowiedzi prasowej (jwp) poświęconych wyborom

\begin{tabular}{|c|c|c|c|}
\hline \multirow{2}{*}{ Miasto } & \multicolumn{2}{|c|}{ Dziennik } & \multirow{2}{*}{$\begin{array}{c}\text { Razem opublikowanych jwp } \\
\text { w regionie }\end{array}$} \\
\hline & „Gazeta Wyborcza” & „Polska The Times” & \\
\hline Katowice & 51 & 46 & 97 \\
\hline Kraków & 75 & 94 & 169 \\
\hline Poznań & 60 & 77 & 137 \\
\hline Warszawa & 44 & 24 & 68 \\
\hline
\end{tabular}

Na liczbę artykułów wpływ mogła mieć zaciętość wyborczej rywalizacji w poszczególnych miastach o fotel prezydenta, w mniejszym stopniu 
także o miejsca w radzie miasta. Wpływ mogły wywrzeć również przewidywania wynikające $\mathrm{z}$ danych sondażowych, dotyczących wyborczych szans rywalizujących podmiotów, zwłaszcza na poziomie prezydentów miast. W Warszawie wynik wyborów był właściwie przesądzony, również w Poznaniu i Katowicach pozycja sprawujących urząd wydawała się niezagrożona. Natomiast w Krakowie rywalizacja pomiędzy głównymi kandydatami na urząd prezydenta Krakowa była znacznie bardziej zacięta, przez co kampania wyborcza bardziej interesująca, w szczególności dla mediów, co miało najprawdopodobniej znaczący wpływ na tak duże zainteresowanie prasy kampanią na tle innych miast oraz przełożyło się na intensywność kampanijnych relacji.

Różnice w sposobie relacjonowania są widoczne nie tylko na poziomie regionów, lecz przede wszystkim pomiędzy samymi tytułami. Te drugie można najlepiej zaobserwować, analizując i porównując ze sobą sposób relacjonowania wyborów w poszczególnych tytułach w określonym mieście. W niniejszym artykule, jako swoistym studium przypadku i jednocześnie punkcie wyjścia do dalszych analiz, omówiono i przeanalizowano sposób relacjonowania wyborów w 2010 roku w Poznaniu. Jest to równocześnie próba ukazania i sprawdzenia metodologii stosowanej w badaniu mediatyzacji kampanii wyborczych przez autorów tego opracowania.

W Poznaniu w okresie dwóch ostatnich tygodni kampanii wyborczej, w 10 wydaniach analizie poddano łącznie 137 jednostek wypowiedzi prasowych. Z tej liczby 77 zostało zamieszczonych w „Głosie Wielkopolskim”, co stanowiło $24,6 \%$ wszystkich jednostek wypowiedzi prasowej - na stronach regionalnych poznańskiej mutacji „The Times" opublikowano w badanym okresie łącznie 312 artykułów. Natomiast w poznańskiej „Gazecie Wyborczej” na 275 opublikowanych w tym okresie tekstów, wyborom poświęconych było 60 , a więc $21,8 \%$. Niniejsza analiza, jako wycinek szerszych badań, zwraca uwagę na najważniejsze kryteria, jakie były brane pod uwagę przy analizie sposobu relacjonowania kampanii, a więc: sposób ekspozycji materiału (powierzchnia oraz występowanie zapowiedzi na pierwszej stronie), opatrywanie tekstów zdjęciami, wykorzystywane gatunki dziennikarskie ${ }^{7}$, zainteresowanie określonymi poziomami rywalizacji wyborczej, ramy

7 W książce kodowej do wyboru były: informacja, artykuł publicystyczny, felieton (jeśli nazwany felietonem), komentarz (jeśli nazwany komentarzem), wywiad, dyskusja redakcyjna, biografia, profil, portret, list i ,inne”. 
tematyczne stosowane przez dziennikarzy ${ }^{8}$, poruszana problematyka, sposób prezentacji ${ }^{9}$ oraz osoby, które wypowiadały się w materiałach poświęconych wyborom.

Ilościowa analiza zebranego w Poznaniu materiału przedstawia się następująco. Po pierwsze, na ogólną liczbę 137 jednostek poświęconych wyborom, $115 \mathrm{z}$ nich (83\%) dotyczyło bezpośrednio wyborów, w pozostałych tematyka wyborcza została jedynie zasygnalizowana. Wśród analizowanych artykułów dominowały teksty o wielkości mniejszej niż pół strony. Tekstów tej wielkości opublikowano 71 (51,8\%), natomiast jedynie 35 z nich $(25,5 \%)$ swoją wielkością przekroczyło pół strony. Jeżeli uznamy, że o wadze materiału prasowego świadczy zapowiedź na pierwszej stronie, to fakt, iż 20 artykułów (co daje 14,6\%) taką zapowiedź na pierwszej stronie miało, zdaje się potwierdzać, że prasa regionalna uznała wybory samorządowe jedynie za kolejne, choć oczywiście bardzo istotne wydarzenie. $Z$ pewnością jednak temat ten nie zdominował całkowicie przekazu. Można powiedzieć, że stopień zainteresowania wyborami był w jakimś stopniu odpowiedzią na poziom frekwencji wyborczej w poprzednich wyborach do samorządu terytorialnego. Ponadto, skoro większość jwp nie przekraczała swoją objętością pół strony, trudno się dziwić, że tylko 45,3\% tekstów było zilustrowanych zdjęciem - w 62 materiałach (na 137) pojawiło się łącznie 125 zdjęć. Na prawie wszystkich zdjęciach (103 - co daje 83,1\%) występowały podmioty rywalizujące w wyborach, najczęściej pojedyncze osoby (91 - 73,4\%), jedynie 15 (12,1\%) zdjęć miało charakter zbiorowy, a więc występowały na nim więcej niż 4 osoby. Publikowane zdjęcia miały charakter publiczny $(104-83,9 \%)$, prezentując kandydatów w oficjalny sposób. Niemal wszystkie były też nacechowane neutralnie $(88-71 \%)$.

8 Zaproponowaliśmy następujące ramy: strategiczną (zwracającą uwagę na taktykę wyborcza, działanie, opis strategii wyborczych, tworzenia list itp.), programową (kładącą nacisk na treści, postulaty, program), personalną (skupiającą uwagę na kompetencjach moralnych i merytorycznych kandydata/ów), regulacyjną (omawiającą regulacje prawne dotyczące wyborów), ramę skandalu (podkreślającą rangę wydarzeń skandalizujących, afer) i „inne”.

9 W tym przypadku wybór dotyczył następujących sposobów: informacyjnego (czysta informacja), publicystycznego (informacja z tłem - komentarzem, opisem bez nacechowania), polemicznego/krytycznego (kiedy to dziennikarz jawnie polemizuje z rozwiązaniem/podmiotem), ironicznego/prześmiewczego (pełnego sarkazmu), postulatywnego (kiedy to sam dziennikarz postuluje rozwiązania lub inny). 
Prosta analiza ilościowa pokazuje więc, że temat wyborów nie był nadmiernie eksponowany na łamach gazet regionalnych w najbardziej gorącym przedwyborczym czasie, skoro dwa najważniejsze regionalne tytuły poświęciły wyborom $23,2 \%$ opublikowanych w tym czasie tekstów, w dodatku niezbyt obszernych i w większości pozbawionych ilustracji. A należy pamiętać, że w Poznaniu wynik pierwszej tury wyborów na prezydenta miasta, a szczególnie wynik wyborów do rady miasta nie był z pewnością przesądzony, co potwierdziły zresztą wyniki I tury wyborów prezydenckich ${ }^{10}$.

Ważnym kryterium w opisie relacjonowania kampanii w prasie są gatunki dziennikarskie. Wybór przez dziennikarza określonego gatunku daje w pewnym stopniu odpowiedź na pytanie o cel, jaki stawiali sobie dziennikarze - czy ich zadaniem było tylko neutralne, faktograficzne przedstawianie przebiegu kampanii, czy też mieli zamiar otwarcie polemizować z kandydatami i pokazywać wyborcom mocne, ale i słabe strony kandydatów, a więc w pewnym sensie na ile chcieli realizować rzeczywistą funkcję czwartej władzy, na ile podjęli trud inicjowania, prezentując własne stanowiska, publicznej debaty. Czy dominował opis, czy też ocena?

Badania na próbie poznańskiej pokazały, że informacja przeplatała się z publicystyką. Najwięcej, bo 36 jwp (26,3\%) miało charakter typowo informacyjny, prawie tyle samo, bo $34(24,8 \%)$ zakodowano jako artykuły publicystyczne. Niewiele mniej bo 28 (20,4\%) jwp miało charakter relacji $\mathrm{z}$ różnych dziejących się $\mathrm{w}$ trakcie kampanii wydarzeń - konferencji prasowych, debat czy innych pseudowydarzeń. Na łamach analizowanej prasy opublikowano 15 wywiadów, głównie z kandydu-

10 W jej efekcie doszło do II tury wyborów na prezydenta, a Platforma Obywatelska w radzie miasta otrzymała wynik poniżej oczekiwań. Wyniki wyborów w Poznaniu w 2010 roku przedstawiają się następująco: w pierwszej turze Ryszard Grobelny otrzymał 49,52\% głosów, drugi Grzegorz Ganowicz popierany przez PO $21,53 \%$. W drugiej turze urzędujący prezydent Ryszard Grobelny wygrał zdecydowanie, otrzymując poparcie $66,26 \%$ poznaniaków. W wyborach do rady miasta PO otrzymała 37,3\%, KWW Ryszarda Grobelnego 18,47\%, PIS 18,18\%, SLD 14,62\% a z komitetów, które przekroczyły $5 \%$ próg wyborczy wymienić należy jeszcze KWW Porozumienie My Poznaniacy z wynikiem 9,32\%. PO uzyskała więc jedynie 17 mandatów w 37 osobowej radzie miasta, komitet prezydenta 8 mandatów, PIS 7, a SLD 5. Głosy tak się rozłożyły, że stowarzyszenie My Poznaniacy, pomimo bardzo dobrego wyniku, ostatecznie nie wprowadziło nawet jednego radnego do rady miasta. Źródło: www.pkw.gov.pl (dostęp: 22.06.2012 r.). 
jącymi politykami (10,9\% ogółu materiałów) oraz 6 krótkich komentarzy (4,4\% jwp). Wyniki trudno uznać za zaskoczenie, potwierdziły one, że choć ilościowo wybory nie zdominowały prasy regionalnej w takim stopniu, jak można było przypuszczać, to jednak dziennikarze nie ograniczyli się do prostego informowania i nie stronili od polemik i ocen. Prasa, pomimo małej ilości komentarzy redakcyjnych, starała się jednak poprzez publicystykę w jakimś stopniu pomagać wyborcom w dokonaniu wyboru, przedstawiając najważniejsze problemy samorządów i pomysły kandydatów na ich rozwiązywanie.

Używanie terminu „samorządów” sugerować może, że prasa regionalna swoim zainteresowaniem obejmowała wybory na wszystkich szczeblach w regionie. Nic bardziej mylnego. Badanie jednoznacznie wykazały, że zainteresowanie dotyczyło głównie najbardziej medialnych pojedynków wyborczych, toczących się w dużych miastach, w analizowanym przypadku w Poznaniu. Media relacjonowały głównie to, co najbardziej interesujące i bliskie dla ich głównego, mimo teoretycznego zasięgu, czytelnika - mieszkańca stolicy regionu. Region praktycznie na łamach prasy nie zaistniał, mimo formalnie dużego znaczenia na przykład wyborów do sejmiku.

W pewnym uproszczeniu można stwierdzić, że dziennikarzy poznańskiej prasy regionalnej (a nie lokalnej, o czym należy pamiętać) interesowały tylko wybory na prezydenta Poznania oraz do Rady Miasta Poznania. Najczęściej artykuły dotyczyły wyborów na prezydenta - poświęcono im 65 publikacji $(47,4 \%)$, nieco mniej bo $54(39,4 \%)$ omawiało wybory do poznańskiej rady miasta. Wybory do pozostałych jednostek samorządowych na łamach dwóch badanych dzienników ledwo zaistniały. W jedynie 16 artykułach (11,7\% ogółu jwp) pisano o wyborach do sejmiku wojewódzkiego, 15 tekstów (10,9\%) dotyczyło wyborów na burmistrzów i wójtów w innych miastach/gminach w województwie, w 9 materiałach $(6,6 \%)$ dziennikarze opisywali zmagania o fotel prezydenta innego wielkopolskiego miasta, a w 8 jwp $(5,8 \%)$ pojawiła się informacja o przebiegu rywalizacji do rad powiatów. Dziwić i martwić w zasadzie powinien zwłaszcza niski poziom zainteresowania bardzo istotnymi z punktu widzenia funkcjonowania i rozwoju regionu - województwa, wyborami do sejmiku. Nikłe zainteresowanie wyborami poza Poznaniem pokazuje, że prasa regionalna w praktyce stała się prasą jednej aglomeracji. Strony pierwotnie regionalne, dziś wydaje się, że już głównie z nazwy, ograniczają się do stolicy regionu, gdyż w innych miastach funkcję tę spełnia dużo lepiej prasa lokalna, zarówno na 
co dzień, jak i podczas kampanii wyborczej. Jeżeli już omawiano wybory $\mathrm{w}$ regionie, to dominowały ciekawostki, w rodzaju prezentacji najmłodszych kandydatów na radnych w województwie.

Skoro już wiadomo, ile miejsca poświęcono wyborom i jakich szczebli oraz w jaki sposób pisano o przebiegu kampanii, kolejną istotną kwestią okazało się zbadanie, jakie, zgodnie z koncepcją framingu, ramy tematyczne dziennikarze narzucają odbiorcom. Analiza dwóch poznańskich dzienników pokazała, że w trakcie kampanii dominowała rama programowa (38 jwp - 27,7\%) i rama personalna $(37-27 \%)$, choć $\mathrm{w}$ niewiele mniejszym stopniu dzienniki stosowały również ramę strategiczną (32 jwp - 23,4\%). Natomiast tylko 11 tekstów (8\%) zawierało elementy skandalizujące, a $7(5,1 \%)$ poruszało kwestie regulacyjne - ordynacji wyborczej i innych formalno-prawnych aspektów prowadzenia kampanii wyborczych i organizacji wyborów. Dziennikarze swoje teksty poświęcali głównie propozycjom programowym kandydatów, starając się również analizować kampanijne zachowania polityków. Lektura tych artykułów potwierdza również personalizację dzisiejszych wyborów, skoro praktycznie na równi z ramą programową występowała rama personalna - dziennikarze zajmowali się samymi kandydatami, ich dokonaniami w sferze polityki i poza nią. Zwracano często uwagę na rywalizację pomiędzy konkretnymi osobami, kandydatami na urząd prezydenta lub fotel radnego.

Wraz z wykorzystywaniem ram programowej, personalnej i strategicznej, zdecydowanie najczęściej poruszanym przez dziennikarzy w materiałach tematem był po prostu sam przebieg kampanii - pisano o tym w 68 artykułach (49,6\%). Prasa rzeczywiście relacjonowała więc przede wszystkim to, co istotnego jej zdaniem działo się w jej trakcie. W dalszej kolejności zajmowała się konkretną problematyką poruszaną przez kandydatów. Z kwestii merytorycznych na plan pierwszy wybijała się infrastruktura drogowa, o której pisano w 41 materiałach $(29,9 \%$ ogółu jwp). Można więc odpowiedzialnie stwierdzić, że głównym tematem kampanii wyborczej w Poznaniu, z perspektywy dziennikarzy relacjonujących jej przebieg, były drogi. Na drugim miejscu (31 tekstów - 22,6\%), znalazł się temat także związany z infrastrukturą, tym razem jednak niedrogowa, a konkretnie inwestycje. Dziennikarze i kandydaci oceniali dotychczas oddane inwestycje - ich poziom, sposób realizacji, oraz odnosili się do tych, których nie udało się doprowadzić do końca. Ponadto dyżurnym tematem były przyszłe inwestycje i plany w tym zakresie poszczególnych kandydatów. W dalszej kolejności pod względem 
częstotliwości pojawiania się w materiałach znalazła się jakość życia mieszkańców (26 jwp - 19\%), następnie polityka ekonomiczna gminy (19 jwp - 13,9\%) i polityka finansowa (16 jwp - 11,7 \%). Pisano również o funkcjonowaniu instytucji samorządowych (15 jwp - 10,9\%), kulturze i rozrywce (13 jwp - 9,5\%) oraz transporcie publicznym (10 jwp - 7,3\%). Biorąc pod uwagę zadania i budżety gmin, dziwić może, że tylko 8 materiałów poświęcono problematyce edukacji (5,8\%). Sposób relacjonowania tematów kampanii pokazał więc wyraźnie, że głównym punktem agendy podczas kampanii wyborczej, podnoszonym przez prasę, były kwestie inwestycji w infrastrukturę, a więc to, co najbardziej widoczne, a zarazem dla przeciętnego mieszkańca najbliższe i decydujące o poziomie zadowolenia z władz samorządowych.

Kwestie te były przez dziennikarzy prezentowane w zdecydowanej większości w czysto informacyjny sposób - 75 materiałów $(54,7 \%)$ miało taki charakter. Znacznie rzadziej pojawiały się artykuły publicystyczne (32 teksty - 23,4\%). Jeszcze rzadziej dziennikarze wchodzili w otwarta polemikę, jednoznacznie krytycznie podchodząc do problemu lub osoby (13 jwp - 9,5\%). Sympatyzowanie z jakimś kandydatem czy ugrupowaniem można było zauważyć jedynie w 4 artykułach (2,9\%). Jak można było przypuszczać, dziennikarze obu tytułów prasowych dystansowali się od kandydatów, chcąc za wszelką cenę uniknąć podejrzeń o „ciche” choćby wspieranie któregoś z nich, przez co albo neutralnie i maksymalnie obiektywnie starali się informować, albo mniej lub bardziej krytycznie oceniali ich działania lub propozycje. Tym samym potwierdziła się niejako przy okazji kolejna opinia, iż dziennikarze obiektywizm i bezstronność łączą znacznie częściej z krytyką, niekiedy za wszelką cenę, niż z pozytywną opinią.

Jeśli natomiast chodzi o osoby, których wypowiedzi można było przeczytać w materiałach dziennikarskich, to najczęściej wypowiadali się sami kandydaci - ich słowa można było przeczytać w 69 tekstach (50,4\%). Zdecydowanie rzadziej wypowiadali się, bezpośrednio prezentując swoje zdanie, sami dziennikarze (w 20 jwp - 14,6\%). Najbardziej dziwi jednak fakt, że tylko w 20 materiałach (14,6\%) znalazły się wypowiedzi ekspertów - najczęściej przedstawicieli nauki. Dziwi to nie tylko z perspektywy powszechnie przyjętej praktyki sięgania po zdanie ekspertów, co zwykle podnosi merytoryczną zawartość tekstów. Brak ekspertów świadczy o odchodzeniu od ugruntowanej dziennikarskiej zasady, że w materiale przedstawiamy racje obu stron oraz opinie eksperta, która pozwala czytelnikowi na wyrobienie sobie własnego zdania. Niezbyt 
często dziennikarze sięgali również po wypowiedzi przedstawicieli sztabów wyborczych $(8-5,8 \%)$. W efekcie znaczna część tekstów to po prostu cytaty lub parafraza wypowiedzi kandydatów na samorządowe funkcje, a więc najłatwiejszy sposób przygotowania tekstu o kampanii.

\section{Podsumowanie i wnioski}

Podejmując się podsumowania wyników omówionego powyżej, warto jeszcze raz wyraźnie zaznaczyć - pilotażowego badania, należy stwierdzić, że pozytywnie zweryfikowany został klucz kodowy, przyjęty na potrzeby analizy. W praktyce obroniła się więc zastosowana do analizy ilościowej metoda badawcza. Ogólne wnioski co do sposobu relacjonowania przebiegu kampanii wyborczej w poznańskiej regionalnej prasie drukowanej są natomiast następujące. Przede wszystkim, badane dwa dzienniki regionalne zainteresowane były głównie wyborami na prezydenta miasta wojewódzkiego i do jego rady, a w bardzo niewielkim stopniu, zwłaszcza przy uwzględnieniu wagi wyborów do samorządu województwa, wyborami do sejmiku. Jeśli chodzi o formę, to dominującymi gatunkami była informacja oraz publicystyka. Ponadto pojawiło się dużo krótkich notek informacyjnych, a mniej niż 50\% tekstów zostało opatrzonych zdjęciami. Oba dzienniki głównie relacjonowały przebieg kampanii, poza tym z podnoszonych tematów dominowały zagadnienia związane $\mathrm{z}$ infrastrukturą miasta, $\mathrm{i}$ to głównie drogową. $\mathrm{W}$ tekstach relacjonujących kampanię względnie mało było ostrych polemik i twardej krytyki, dominował za to głównie informacyjny sposób przedstawiania tematu. Dziennikarze tych dzienników nie włożyli, jak się wydaje, wielkiego wysiłku w autorskie przygotowywanie materiałów, gdyż głównie cytowali lub co najwyżej parafrazowali kandydatów, względnie rzadko wzbogacali swoje teksty opiniami ekspertów.

Analiza wykazała jednak również różnice w sposobie relacjonowania kampanii przez „Gazetę Wyborczą” i „Głos Wielkopolski”, na tyle istotne, że ich pominięcie nadmiernie uprościłoby niniejszą analizę. Przede wszystkim w poznańskiej „Gazecie Wyborczej” aż 90\% tekstów poruszało temat rywalizacji wyborczej bezpośrednio, podczas gdy w „Głosie Wielkopolskim” tylko 79,2\%. Co ciekawe, w „Gazecie Wyborczej” tylko w 12 jwp były zdjęcia (20\%), gdy w „Głosie Wielkopolskim” aż w $50(64,9 \%)$. W „Głosie Wielkopolskim” jako dzienniku typowo informacyjnym, dominowała informacja (33,8\% i tylko 20\% publicystyki), 
a w opiniotwórczej od początku jej istnienia „Gazecie Wyborczej” zdecydowanie więcej było publicystyki (30\% i tylko 16,7\% informacji). „Gazeta Wyborcza” ograniczyła się praktycznie tylko do wyborów na Prezydenta Poznania i do Rady Miasta Poznania. Natomiast „Głos Wielkopolski”, jak przystało na tytuł regionalny, znacznie częściej poruszał kwestie wyborów do sejmiku, do rad powiatów oraz innych gmin w województwie (po kilkanaście procent tekstów wspominało o wyborach poza Poznaniem). W „Głosie Wielkopolskim” dominowała rama personalna $(28,6 \%)$, programowa, $(26 \%)$ i strategiczna $(20,8 \%)$, w „Gazecie Wyborczej" te same, lecz w innej kolejności - programowa (30\%), przed strategiczną $(26,7 \%)$ i personalną $(25 \%)$. Oba pisma głównie opisywały przebieg wyborów (48,3\% i 50,6\%), w „Głosie” więcej było natomiast materiałów poruszających problem polityki ekonomicznej i finansowej gminy. I wreszcie, „Głos Wielkopolski” wybrał zdecydowanie informacyjny sposób prezentacji (61\%) kosztem publicystyki $(16,9 \%$,). Natomiast w "Gazecie Wyborczej” obok informacji (46,7\%), obecna była i publicystyka $(31,7 \%)$, i polemika $(13,3 \%)$.

W świetle powyższych ustaleń nasuwają się jeszcze bardziej ogólne wnioski dotyczące badania. Po pierwsze, zastosowana metoda badawcza do badania sposobu relacjonowania kampanii wyborczych w kontekście ich mediatyzacji, w tym przede wszystkim książka kodowa, okazała się na tyle precyzyjna, że z pewnymi modyfikacjami będzie stosowana w trakcie analizy kolejnych wyborów samorządowych, co da w przyszłości unikatową możliwość porównania relacjonowania kolejnych wyborów, a tym samym odpowiedzi na pytanie, czy mamy do czynienia z incydentalnym relacjonowaniem kampanii, czy też z ogólnymi tendencjami, a jeśli tak, to jakimi. Po drugie, zastosowane kryteria pozwalaja określić podejście dziennikarzy do relacjonowania kampanii wyborczej, a więc dość precyzyjnie opisać i wyjaśnić charakter i specyfikę dziennikarskich relacji z samorządowej rywalizacji wyborczej. Po trzecie, już na tym etapie badań można stwierdzić, że w każdym regionie, niezależnie od takiego samego pochodzenia badanych tytułów prasowych, relacjonowały one kampanie w nieco inny sposób, inaczej rozkładały akcenty. Po czwarte, różnice występowały również pomiędzy dziennikami w danym regionie, czego dobrym przykładem okazała się właśnie Wielkopolska. I po piąte - analiza pokazała, że poziom mediatyzacji wyborów w samej prasie regionalnej wcale nie jest najwyższy, jeżeli główną miarą byłaby tylko liczba (oraz wielkość) jednostek wypowiedzi prasowej poświęconych wyborom. Wydaje się, że prasa regionalna, borykająca 
się z problemem spadku sprzedaży i pozyskiwaniem dochodów z reklam, uznała, że nawet na finiszu kampanii poświęcanie wyborom szczególnego zainteresowania i pomijanie innych aktualnych tematów, niekoniecznie przysporzy jej czytelników, z których i tak znaczna część do wyborów nie pójdzie (nawet zakładając, że wśród czytelników dzienników regionalnych frekwencja jest wyższa niż wśród osób niesięgających po tego rodzaju prasę).

Szczegółowa, pełna analiza wszystkich miast, z obszernym ich porównaniem, zostanie dokonana w odrębnej publikacji zbiorowej poświęconej mediatyzacji i profesjonalizacji samorządowej kampanii wyborczej, w tym jej relacjonowaniu w prasie regionalnej, która ukaże się jeszcze w tym roku.

\title{
Coverage of the elections in the regional media in Poland in 2010. A report from the study
}

\begin{abstract}
Summary
The paper presents the methodology and partial results of an empirical study on the professionalization and mediatization of the local government election campaign from the perspective of its coverage by the regional press. The study was conducted by a research team from four academic centers in Poland, under a research project entitled The elections to local governments in regional media. Regional dailies and television election programs as platforms of political communication. One of the aims of the project was to analyze how election campaigns were covered by local press at the time of the local government election campaign in Poland in 2010. Quantitative and qualitative methods of analysis were applied to the content of press releases concerning the elections collected over the last two weeks of the election campaign, prior to the elections of $21^{\text {st }}$ November 2010, in the regional issues of the printed versions of "Gazeta Wyborcza" and regional variations of the "Polska The Times", published in four regional capitals - Katowice, Kraków, Poznań and Warsaw. In the case of newspapers, an examined entity was a press release on the elections.
\end{abstract}


